REVIEW

\title{
Methadone: applied pharmacology and use as adjunctive treatment in chronic pain
}

\author{
R Brown, C Kraus, M Fleming, S Reddy
}

Postgrad Med J 2004;80:654-659. doi: 10.1136/pgmj.2004.022988

This article reviews the unique pharmacological properties of methadone and outlines its appropriate clinical application, with focus upon its use in the treatment of chronic pain. Although methadone is most widely known for its use in the treatment of opioid dependence, methadone also provides effective analgesia. Patients who experience inadequate pain relief or intolerable side effects with other opioids or who suffer from neuropathic pain may benefit from a transition to methadone as their analgesic agent. Adverse effects, particularly respiratory depression and death, make a fundamental knowledge of methadone's pharmacological properties essential to the provider considering methadone as analgesic therapy for a patient with chronic pain.

See end of article for authors' affiliations

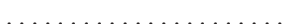

Correspondence to: Dr Randall Brown, University of Wisconsin Department of Family Medicine, 777 S Mills St, Madison, WI 53715, USA; rtbrown@fammed.wisc. edu

Submitted 14 April 2004 Accepted 10 May 2004
M ethadone is a synthetic opioid medication best known for its use in the treatment of opioid dependence. Methadone is also an effective analgesic agent, potentially with increased efficacy in the setting of neuropathic pain. ${ }^{1-3}$ Patients experiencing inadequate analgesia or adverse effects while on other opioids may also benefit from a transition to methadone. ${ }^{1-11}$ Additionally, unique pharmacological properties make methadone a useful addition to the care provider's arsenal of prescription analgesic agents.

Methadone's excellent oral bioavailability and mucosal absorption, effectiveness as an analgesic agent, low cost, long half life, and availability in oral, parenteral, and suppository forms make it an excellent alternative for the treatment of both cancer and non-cancer pain. ${ }^{8}$ Medication interactions and the potential for serious adverse effects (particularly central apnoea and death, which have received recent attention in the popular press) ${ }^{12-14}$ make an understanding of methadone's pharmacological profile essential to the prescribing provider.

Many individuals participating in methadone maintenance treatment for opioid dependence seek medical care in the community outside of their addiction treatment facility. An understanding of potential adverse effects and medication interactions is important when caring for this population as well, so that the provider can avert untoward events resulting from medication interactions.

In this article, we discuss the pharmacology of methadone and briefly comment upon its use in the treatment of opioid dependence and withdrawal. We then focus upon an approach to the prescription of methadone for the treatment of chronic pain conditions. Finally, we discuss the adverse effects of and potential drug interactions with methadone which may occur with usual clinical use.

\section{PHARMACOLOGY}

Methadone occurs in R-enantomeric and Senantomeric forms, with essentially all of its activity due to activity of R-methadone. ${ }^{15}$ Methadone exerts its activity through binding to and activating $\mu$ opioid receptors centrally and in the periphery. This activity produces the effects common to all $\mu$ opioid agonists: analgesia, euphoria, constipation, sedation, respiratory depression, nausea, and miosis. Additionally, methadone antagonises $N$-methyl-D-aspartate receptors, which may increase its effectiveness in the treatment of neuropathic pain compared with other opioids. ${ }^{16}$

\section{Pharmacokinetics}

Methadone is a fat soluble drug which is rapidly absorbed after oral administration. Time to peak concentration, however, varies from one to five hours. Methadone induced slowing of gastric emptying may account for longer time to peak concentration in chronic users. Oral bioavailability of tablets is approximately $60 \%-70 \%$, but wide variation among patients exists. ${ }^{15}$ The analgesic effect of a dose begins within 30 to 60 minutes after administration and generally lasts for four to six hours. ${ }^{3}$

Methadone is highly bound to plasma proteins. In particular, $\alpha_{1}$-acid glycoprotein is important, because disease states, like cancer, may induce a rise in the concentration of this protein and, as a result, affect the concentration of free methadone. ${ }^{15}$ Certain drugs may influence $\alpha_{1}$-acid glycoprotein concentrations and, in turn, methadone concentrations. Methadone may be displaced from plasma proteins by drugs like propranolol, certain phenothiazines, and imipramine. Other drugs may decrease plasma protein and, theoretically, increase free methadone levels. Examples of such drugs are carmustine and mechlorethamine. Finally, drugs may also selectively compete for protein binding sites, resulting in situations where their own free levels might increase. The tricylic antidepressants, progesterone, and lidocaine are a few examples. Although animal data suggest that dose adjustments based on protein binding may be necessary, there are no data in humans to suggest these interactions are clinically significant. ${ }^{17}$ 
Methadone is also widely distributed to tissue, and, with continuous use, tissue levels may exceed levels in plasma. This extensive protein and tissue binding is responsible for the long plasma half life of the drug, particularly with continuous use. ${ }^{9}$

Metabolism of methadone to inactive forms is the principle means of elimination. ${ }^{15}$ Less than $10 \%$ of an oral dose is extracted by the liver during first pass. ${ }^{9}$ The drug is metabolised both by the liver and by intestinal CYP $3 \mathrm{~A} 4$ and, to a lesser extent, by CYP 2D6. Some of the variability of enzyme activity in different people likely accounts for the large differences in clearance and half life of methadone seen within a population. ${ }^{15}$ For example, due to a polymorph of CYP 2D6, a subset of the white population, less than $10 \%$, are considered to be poor metabolisers of methadone. ${ }^{18}$ Estimates of methadone half life vary from 15 to 55 hours. In addition to metabolic inactivation, parent drug and metabolites are also eliminated in the faeces and urine..$^{15}$

Age does not appear to have a large influence on clearance and generally no change in dose is required for persons over age 65 years. For patients with impaired renal function, methadone clearance via faeces will increase and no dose adjustment is necessary. For patients with end stage renal disease, some experts suggest a $50 \%$ reduction in methadone dosing. Because methadone is highly protein bound, little is expected to be removed from the plasma with dialysis. Patients with chronic, stable liver diseases may be able to tolerate usual methadone maintenance doses. For patients with acute hepatitis and elevated liver enzymes, higher doses of methadone may be required..$^{15} 19$

No relationship has been established between plasma concentration and analgesic effect. ${ }^{9}$ For the treatment of chronic pain, treatment should be titrated to clinical effect rather than a drug level. ${ }^{3}$

\section{CLINICAL APPLICATIONS}

\section{Methadone for opioid dependence}

Since the enactment of the Narcotic Addicts Treatment Act in 1973, methadone prescription in the United States for opioid dependence or opioid withdrawal has been (and continues to be) legal only in the setting of a federally licensed methadone maintenance facility..$^{20}$ Resources for the care of health issues unrelated to substance abuse are often limited in these facilities. Methadone maintained individuals, therefore, frequently seek medical care from community providers.

Over 150000 opioid dependent individuals are enrolled in methadone treatment centres in the United States. The United States Office of National Drug Control Policy estimates that these services reach one in 10 to one in eight actively opioid dependent individuals in the United States. ${ }^{21}$

Methadone maintenance treatment has been shown to decrease use of heroin and other drugs; reduce the acquisition and transmission of HIV, ${ }^{22}{ }^{23}$ hepatitis B, and hepatitis $\mathrm{C}^{24}$; reduce criminal behaviour ${ }^{25}$; and has been shown to be a cost effective treatment for opioid dependence. ${ }^{26}$ Most of the benefits of methadone maintenance have been shown to be related to methadone dose and to duration of treatment. 202728

\section{Methadone for chronic pain}

Federal and state regulations restricting the use of methadone in the setting of opioid dependence and withdrawal to specially licensed facilities do not apply to the prescription of methadone for chronic pain. Therefore, the care provider may consider the use of methadone as an analgesic agent for the treatment of chronic pain.

In addition to being effective treatment for opioid dependence, methadone provides effective analgesia with several unique properties. Patients experiencing adverse effects (constipation, euphoria, nausea/vomiting) or inadequate analgesia with other prescribed opioids may benefit from a transition to methadone. ${ }^{57}$ Additionally, methadone often provides analgesia superior to other opioids in the setting of neuropathic pain syndromes. ${ }^{3}$ Furthermore, a reduced level of tolerance to analgesic effects and less constipation has been reported for methadone as opposed to other opioids. ${ }^{6}$

Given the short duration of analgesia (4-6 hours) relative to methadone's half life, the use of methadone as an analgesic agent requires a more frequent dosing regimen than the daily dosing used for the treatment of opioid dependence. Usual analgesic treatment regimens with methadone require dosing every eight to 12 hours. The long half life of methadone in the setting of more frequent dosing creates the potential for drug accumulation and adverse effects. Many protocols for a transition to methadone from other opioid analgesics have been put forward in the literature. $^{1242930}$ These methods are of two basic types: (1) a rapid transition in which the previously prescribed opioid is completely discontinued with institution of methadone analgesic therapy, and (2) a slow transition in which the previously prescribed opioid is tapered in conjunction with titration of methadone dosing. Equianalgesic doses of the most commonly prescribed opioids are provided in table 1.

Boxes 1 and 2 provide examples of each protocol (slow and rapid) for transition to methadone using morphine milligram equivalents.

Though not generally a first line agent, methadone may be considered early on in the treatment of neuropathic pain and/ or in situations where cost issues are compelling. This situation mandates caution because, in the opioid naïve patient, methadone may precipitate respiratory arrest. A history of sleep apnoea, severe asthma or respiratory failure, right heart failure, morbid obesity, or the concurrent use or abuse of sedative drugs (for example, alcohol, muscle relaxants) increase the risk of respiratory depression or arrest with methadone. The first visit with the care provider should, therefore, include a detailed medical history to screen for these high risk situations. A methadone regimen for chronic pain in the opioid naïve patient may then begin with a low dose (5 $\mathrm{mg}$ or less twice daily) and be gradually (an additional $5 \mathrm{mg}$ daily every 72 hours) titrated upward to pain relief. Total daily doses exceeding $120 \mathrm{mg}$ are rarely required to provide adequate 24 hour analgesia. ${ }^{1}$ As needed doses of short acting analgesics, such as oxycodone, hydrocodone, or short acting morphine preparations, may be considered for the treatment of breakthrough pain.

An optimal concentration of methadone for maintenance therapy for opioid dependence is considered to be $400 \mu \mathrm{g} / \mathrm{l}$, although in some studies, designed to determine an effective concentration, a threshold was not found. On the other hand, some patients will have a reasonable clinical response with lower serum concentrations and other factors such as receptor sensitivity, social support, and psychological issues may also play a part. Therefore, therapeutic drug monitoring

\begin{tabular}{ll} 
Table 1 & Opiate milligram equivalents* \\
\hline Drug & Equianalgesic doses \\
\hline Codeine & $180-200 \mathrm{mg}$ \\
Fentanyl & $25 \mu \mathrm{g} \mathrm{transdermal}$ \\
Hydrocodone & $30 \mathrm{mg}$ \\
Morphine & $30-60 \mathrm{mg}$ oral \\
Oxycodone & $30 \mathrm{mg}$ \\
\hline *Methadone conversion is not included due to varying \\
conversion ratios at varying prior doses of other opiates. See \\
boxes 1 and 2 for appropriate conversion to methadone \\
based upon morphine milligram equivalents.
\end{tabular}


Box 1: United Kingdom model for switching from morphine to methadone (rapid transition)

- The use of the previous opiate is stopped and replaced by a fixed dose of methadone. A patient who was receiving $300 \mathrm{mg}$ or less of morphine milligram equivalents daily would have the dose replaced at a ratio of $10 \mathrm{mg}$ morphine: $1 \mathrm{mg}$ methadone. A patient receiving greater than $300 \mathrm{mg}$ of morphine milligram equivalents daily would receive a fixed dose of $30 \mathrm{mg}$ methadone. This dose is then used at intervals of not less than three hours as needed for analgesia.

- On day 6 , the amount of methadone administered over the previous two days is converted to a regimen delivered regularly at 12 hour intervals.

- Methadone requirements should be expected to decrease during days 2 and 3 and reach steady state on days $4-5$.

is not recommended routinely for all patients receiving methadone maintenance. ${ }^{15}$ No relationship has been established between plasma concentration and analgesic effect. ${ }^{9}$ For the treatment of chronic pain, therefore, treatment should be titrated to clinical effect rather than a drug level. ${ }^{3}$

\section{CESSATION/TAPER OF METHADONE}

Should cessation of methadone treatment be indicated, gradual tapering will minimise withdrawal symptoms. The
Box 2: Edmonton model for switching from morphine to methadone (slow transition) ${ }^{2}$

- Day 1: Decrease morphine dose by $30 \%$ and replace with oral or rectal methadone every eight hours using titration equianalgesic morphine-to-methadone dose ratio of 10:1.

- Day 2: If pain control is adequate, decrease the original dose of morphine by another $30 \%$. Increase the dose of methadone only if the patient experiences moderate to severe pain. Treat transient pain with rescue doses of short acting opioids.

- Day 3: Discontinue the last $40 \%$ of the original morphine dose and maintain the patient on regular methadone administered every eight hours plus about $10 \%$ of the daily methadone dose administered as a rescue dose for breakthrough pain.

taper generally should not exceed $1 \mathrm{mg} /$ day. ${ }^{31}$ A $5 \mathrm{mg} /$ week taper is convenient given methadone's availability in $5 \mathrm{mg}$ and $10 \mathrm{mg}$ tablet forms.

Aching muscles and joints, insomnia, nausea, and mood changes may indicate opioid withdrawal. ${ }^{32}$ If the patient begins to experience opioid withdrawal effects, symptomatic treatments on an as-needed basis may assist in the management of a continued taper if necessary. Clonidine or a $\beta$ blocker may alleviate sympathomimetic symptoms (tachycardia, lacrimation, stuffy nose, sweats). These medications

Table 2 Drug interactions associated with enhanced methadone effects

\begin{tabular}{|c|c|c|c|c|c|}
\hline & Pharmacokinetic effects & Clinical effects & Type of evidence & Possible mechanism & Reference \\
\hline \multicolumn{6}{|l|}{ Antibiotics } \\
\hline Ciprofloxacin & & $\begin{array}{l}\text { Sedation/respiratory } \\
\text { depression/confusion }\end{array}$ & $\begin{array}{l}\text { Single case report; ciprofloxocin } \\
\text { reintroduced with same outcome }\end{array}$ & $\begin{array}{l}\text { Inhibition of CYP1A2 } \\
\text { and/or CYP3A4 }\end{array}$ & 39 \\
\hline Fluconazole & $\begin{array}{l}35 \% \uparrow \text { AUC; } 27 \% \\
\uparrow \text { peak, } 48 \% \uparrow \text { trough, } \\
24 \% \downarrow \text { clearance } \\
\text { methadone }\end{array}$ & $\begin{array}{l}\text { No signs/symptoms of } \\
\text { methadone overdose } \\
\text { reported }\end{array}$ & $\begin{array}{l}\text { Randomised, double blind, } \\
\text { placebo controlled trial; } 13 \\
\text { participants received fluconazole } \\
200 \mathrm{mg} / \text { day }\end{array}$ & $\begin{array}{l}\text { Inhibition of CYP3A4, } \\
\text { possibly others }\end{array}$ & 38 \\
\hline \multicolumn{6}{|l|}{ Antidepressants } \\
\hline Fluoxetine & $\begin{array}{l}\text { Some patients had } \\
\text { moderate } \uparrow \text { plasma level, } \\
\text { but this was less marked } \\
\text { than with fluvoxamine } \\
\text { in the two patients }\end{array}$ & None reported & $\begin{array}{l}\text { Nine case reports of serum levels } \\
\text { of methadone after addition of } \\
\text { fluoxetine; two participants had } \\
\text { also use fluvoxamine previously }\end{array}$ & Inhibition of CYP2D6 & 40 \\
\hline \multirow[t]{2}{*}{ Fluvoxamine } & $\begin{array}{l}\uparrow \text { serum methadone } \\
\text { level }\end{array}$ & Hypoxemia, hypercapnia & Single case & $\begin{array}{l}\text { Inhibition of one of } \\
\text { several enzymes: } \\
\text { CYP3A4, CYP1A2, } \\
\text { CYP2C9, CYP2C19 }\end{array}$ & 41 \\
\hline & $\begin{array}{l}\uparrow \text { serum methadone } \\
\text { level }\end{array}$ & $\begin{array}{l}\text { Patient unable to achieve } \\
\text { effective methadone level } \\
\text { despite high dose. Had } \\
\text { increased methadone level } \\
\text { with fluvoxamine and } \\
\text { decrease in withdrawal } \\
\text { symptoms }\end{array}$ & Single case & $\begin{array}{l}\text { Inhibition of one of } \\
\text { several enzymes: } \\
\text { CYP3A4, CYP1A2, } \\
\text { CYP2C9, CYP2C19 }\end{array}$ & 42 \\
\hline Paroxetine & $\begin{array}{l}\uparrow \mathrm{R} \text {-methadone plasma } \\
\text { levels in eight CYP2D6 } \\
\text { extensive metabolisers } \\
\text { but not in poor } \\
\text { metabolisers }\end{array}$ & $\begin{array}{l}\text { No side effects reported } \\
\text { by patients and no signs } \\
\text { of intoxication were noted }\end{array}$ & $\begin{array}{l}\text { Prospective administration of } \\
\text { paroxetine in } 10 \text { methadone- } \\
\text { using patients (two poor } \\
\text { metabolisers, eight extensive } \\
\text { metabolisers) }\end{array}$ & $\begin{array}{l}\text { Inhibition of CYP2D6; } \\
\text { also possibly CYP1A2, } \\
\text { CYP2C9, CYP2C19, } \\
\text { and CYP3A4 }\end{array}$ & 43 \\
\hline Sertraline & $\begin{array}{l}\uparrow \text { methadone plasma level } \\
26 \% \text { with addition } \\
\text { of sertraline }\end{array}$ & $\begin{array}{l}\text { No significant difference in } \\
\text { side effects between groups }\end{array}$ & $\begin{array}{l}\text { Prospective, } 12 \text { week, } \\
\text { randomised, placebo controlled } \\
\text { trial; } 12 \text { patients received up to } \\
\text { sertraline } 200 \mathrm{mg} / \text { day }\end{array}$ & $\begin{array}{l}\text { Inhibition of several } \\
\text { isoenzymes (CYP2D6, } \\
\text { CYP3A4, CYP1A2, } \\
\text { CYP2C9, CYP2C19) }\end{array}$ & 44 \\
\hline
\end{tabular}

Adapted with permission from Eap CB, Buclin T, Baumann P. Interindividual variability of clinical pharmacokinetics of methadone. Clin Pharmacokinet 2002; 41:1153-93. . $^{15}$

AUC, area under the curve. 
may also alleviate some of the subjective irritability common in opioid withdrawal. Prochlorperazine or promethazine assist in the management of nausea and vomiting. Loperamide will alleviate diarrhoea. Dicyclomine calms abdominal cramping; and a limited supply of a benzodiazepine such as lorazepam, might be considered to assist in the control of insomnia and irritability/anxiety.

\section{SIDE EFFECTS OF METHADONE}

Familiarity with the side effect profile of methadone will assist the practitioner in the appropriate titration of a methadone regimen, will obviate the unnecessary laboratory investigation of signs and symptoms known to be common medication side effects, and may assist the practitioner in the management of these side effects.

Methadone acts upon central opioid receptors, as do the other opioid drugs. This action may reduce hypercapnoeic and hypoxic ventilatory drives resulting in respiratory depression. The most severe potential consequence of this effect is central apnoea. Many cases of mortality due to this effect have been reported. In most situations, medication interactions were missed, medical risk factors ignored, or doses increased too quickly. ${ }^{22}$ Methadone toxicity can also result from inadequately spaced dosage regimens (dosing more frequently than every eight hours) due to the drug's long half life and consequent drug accumulation. ${ }^{17}$ Careful

Table 3 Drug interactions associated with diminished methadone effects

\begin{tabular}{|c|c|c|c|c|c|}
\hline & Pharmacokinetic effects & Clinical effects & Type of evidence & Possible mechanism & References \\
\hline \multicolumn{6}{|l|}{ Antibiotics } \\
\hline Fusidic acid & $\begin{array}{l}\text { Total clearance } \\
\text { antipyrine } \uparrow \text { in group } \\
\text { using fusidic acid } \times \\
28 \text { days }\end{array}$ & $\begin{array}{l}\text { No side effects were } \\
\text { reported by patients; some } \\
\text { patients in } 28 \text { day group } \\
\text { developed signs of } \\
\text { underdosage }\end{array}$ & $\begin{array}{l}\text { Randomised, prospective trial, } \\
\text { placebo controlled. Ten } \\
\text { patients received fusidic acid } \\
500 \mathrm{mg} / \text { day } \times 14 \text { days; } 10 \\
\text { patients with same dose } \times \\
28 \text { days; } 10 \text { patients } \\
\text { received no additional } \\
\text { meds. Antipyrine clearance } \\
\text { used to assess effect on } \\
\text { CYP450 system }\end{array}$ & $\begin{array}{l}\text { Induction of CYP450 } \\
\text { enzymes }\end{array}$ & 46 \\
\hline Rifampin & $\begin{array}{l}\downarrow \text { methadone plasma } \\
\text { level }\end{array}$ & $\begin{array}{l}\text { Methadone withdrawal } \\
\text { symptoms }\end{array}$ & Case & Induction of CYP3A4 & 12,47 \\
\hline \multicolumn{6}{|c|}{$\begin{array}{l}\text { Antivirals/non-nucleoside reverse transcriptase } \\
\text { inhibitors }\end{array}$} \\
\hline Efavirenz & $\begin{array}{l}\text { Marked } \downarrow \text { maximum } \\
\text { plasma methadone } \\
\text { concentration, } \downarrow \text { AUC }\end{array}$ & $\begin{array}{l}\text { Nine patients described } \\
\text { symptoms of methadone } \\
\text { withdrawal }\end{array}$ & $\begin{array}{l}\text { Prospective trial of } 11 \\
\text { patients using methadone } \\
\text { and beginning therapy } \\
\text { with efavirenz }\end{array}$ & Induction of CYP3A4 & 48 \\
\hline \multirow[t]{2}{*}{ Nevirapine } & $\begin{array}{l}\text { Three of seven records } \\
\text { had a documented } \\
\text { decrease in methadone } \\
\text { trough level or } \\
\text { subtherapeutic level }\end{array}$ & $\begin{array}{l}\text { All seven records had } \\
\text { evidence of opiate } \\
\text { withdrawal }\end{array}$ & $\begin{array}{l}\text { Retrospective chart review } \\
\text { of } 800 \text { records of HIV- } \\
\text { infected patients }\end{array}$ & Induction of CYP3A4 & 49 \\
\hline & $\begin{array}{l}36 \% \text { reduction in } \\
\text { maximal concentration } \\
\text { of methadone, } \\
\text { significant } \downarrow \text { AUC }\end{array}$ & $\begin{array}{l}\text { Six of eight patients } \\
\text { reported withdrawal } \\
\text { symptoms }\end{array}$ & $\begin{array}{l}\text { Prospective administration } \\
\text { of nevirapine to eight patients }\end{array}$ & Induction of CYP3A4 & 50 \\
\hline \multicolumn{6}{|c|}{$\begin{array}{l}\text { Antivirals/nucleoside reverse transcriptase } \\
\text { inhibitors }\end{array}$} \\
\hline Abacavir & $\begin{array}{l}\text { Administration of } \\
\text { both abacavir and } \\
\text { ampenavir associated } \\
\text { with median } 65 \% \\
\text { decrease in methadone } \\
\text { concentration }\end{array}$ & $\begin{array}{l}\text { Two patients of the five } \\
\text { reported symptoms } \\
\text { consistent with withdrawal }\end{array}$ & $\begin{array}{l}\text { Prospective administration } \\
\text { of abacavir and ampenavir } \\
\text { to five patients using } \\
\text { methadone }\end{array}$ & $\begin{array}{l}\text { Abacavir not expected to } \\
\text { induce CYP3A4 activity; } \\
\text { the protease inhibitor, } \\
\text { ampenavir, is a known } \\
\text { inducer of CYP3A4 and } \\
\text { more likely the cause of } \downarrow \\
\text { methadone concentration }\end{array}$ & 51 \\
\hline \multicolumn{6}{|c|}{$\begin{array}{l}\text { Antivirals/protease } \\
\text { inhibitors } \\
\text { Amprenavir (see } \\
\text { abacavir statement) }\end{array}$} \\
\hline Nelfinavir & & $\begin{array}{l}\text { Complaint of opiate } \\
\text { withdrawal within six weeks }\end{array}$ & $\begin{array}{l}\text { Single case report nelfinavir } \\
750 \mathrm{mg} \text { three times a day } \\
\text { added to drug regimen }\end{array}$ & $\begin{array}{l}\text { Induction of CYP3A4, } \\
\text { possible induction of } \\
\text { P-glycoprotein }\end{array}$ & 52 \\
\hline $\begin{array}{l}\text { Ritonavir/ } \\
\text { saquinavir }\end{array}$ & $\begin{array}{l}40 \% \downarrow \text { AUC in S- } \\
\text { methadone and } 32 \% \\
\downarrow \text { AUC in R-methadone }\end{array}$ & $\begin{array}{l}\text { No evidence of withdrawal } \\
\text { reported }\end{array}$ & $\begin{array}{l}\text { Prospective pharmacokinetic } \\
\text { study of } 12 \text { patients using } \\
\text { methadone who began } \\
400 \text { mg ritonavir and } \\
400 \text { mg saquinavir twice } \\
\text { daily }\end{array}$ & $\begin{array}{l}\text { Ritonavir: induction of } \\
\text { CYP3A4; possible induction } \\
\text { of P-glycoprotein, induction } \\
\text { of CYP2C19 and/or CYP2B6 } \\
\text { to explain greater induction } \\
\text { of S-methadone } v \text { R- } \\
\text { methadone. In vitro } \\
\text { comparison of inhibition } \\
\text { protency against metabolism } \\
\text { of methadone is ritonavir }> \\
\text { indinavir > saquinavir }\end{array}$ & 53,54 \\
\hline
\end{tabular}

Adapted with permission from Eap CB, Buclin T, Baumann P. Interindividual variability of clinical pharmacokinetics of methadone. Clin Pharmacokinet 2002;41:1153-93. ${ }^{15}$

AUC, area under the curve. 
dose titration, a thorough history for medical risk factors, and cognisance of medication interactions should avert this potentially catastrophic effect.

Due to central opioid receptor activation, somnolence is quite common during the first weeks of treatment before tolerance to this drug effect is gained. Methadone may also interfere with rapid eye movement sleep and sleep stages 3 and 4 . When these changes persist during chronic treatment, insomnia may occur. ${ }^{18}$ Patients experiencing this side effect have lower sleep efficiency, less rapid eye movement, and less slow wave sleep accompanied by sleep disordered breathing. Additionally they spend more time in sleep stage $2 .{ }^{19}$

Methadone maintenance patients may also experience subjective cognitive slowing. Objective, controlled data on this phenomenon are scarce. Tolerance would be expected to this side effect as has been demonstrated with the chronic use of other opioid medications. A European study examining the cognitive effects of chronic methadone therapy concluded that methadone treatment was not, in itself, predictive of impairment in cognitive psychomotor skills; inferior performance on tests was more strongly related to sociodemographic factors. ${ }^{33}$ A second study demonstrated that psychophysical performances and driving aptitude are not significantly related to methadone dose. ${ }^{34}$

Weight gain is a commonly reported side effect among patients on methadone maintenance. The precise aetiology is unclear but may involve appetite increase and/or noncardiogenic peripheral oedema. Previous studies have indicated an onset of weight gain three to six months after initiation of methadone maintenance treatment or after a sharp dosage increase. ${ }^{32} 35$

Sexual dysfunction is also a common complaint of individuals on chronic methadone. In men, orgasm dysfunction and a decrease in libido are the most common concerns. Spermatic dysmotility has also been described. ${ }^{36}{ }^{37}$ Whether or not fertility is adversely affected has yet to be firmly established. Several studies that indicate subnormal levels of plasma testosterone in men maintained on methadone may account for these side effects, though a dose effect relationship has yet to be discovered. ${ }^{38-42}$ Women may experience dysfunction of libido as well as oligomenorrhoea or amenorrhoea. ${ }^{32}$ The aetiology of and potential treatments for these effects are unclear.

Up to $65 \%$ of patients report constipation as a direct effect of methadone. ${ }^{32}$ Tolerance to this peripheral opioid effect may not develop, often necessitating a scheduled bowel regimen during treatment with methadone. ${ }^{43}$

\section{DRUG INTERACTIONS WITH METHADONE}

There are many potential drug interactions with methadone. However, it is difficult to study drug interactions because methadone has a long half life, and time to steady state concentration after a change due to a drug interaction may require up to 10 days. Many of the drug interactions cited in the literature have not been rigorously investigated. ${ }^{19}$ In addition, even though statistically significant change in methadone concentration may occur as a result of a drugdrug interaction, the clinical outcome may not be significant, since methadone has such a wide therapeutic window, and because methadone's half life varies significantly between individuals. ${ }^{44}$ In the setting of a potential drug interaction, therefore, it is reasonable to institute a dosing regimen as described in tables 2 or 3, and monitor the patient closely for signs of supratherapeutic dosing (sedation, euphoria).

Drug interactions with methadone most commonly occur due to inhibition or induction of liver enzymes. Although drugs like older macrolide antibiotics (troleandomycin), ketoconazole, and diazepam are able to inhibit CYP3A4 metabolism of methadone to its inactive metabolite by up to
$80 \%$ in vitro, many of these agents do not exhibit the same degree of inhibition in vivo. ${ }^{15}$ A summary of medications associated with increased concentrations of methadone are found in table $2 .{ }^{44-50}$

Drugs which induce enzyme systems responsible for methadone metabolism may result in lowering of methadone levels. It is thought that chronic abuse of alcohol may increase liver enzymes and reduce methadone levels. ${ }^{19}{ }^{51}$ Seizure medications like phenytoin, phenobarbital, and carbamazepine are classic examples of CYP3A4 enzyme inducers that may lower methadone concentrations. ${ }^{15}$ Of the antibiotics, rifampin has been shown to interfere with methadone. Of the antiviral medications used for the treatment of HIV, the non-nucleoside reverse transcriptase inhibitors increase the metabolism of methadone. Drug interactions resulting in lowered methadone concentrations can be found in table 3 . $^{17} 52-60$

Methadone levels may be affected by competition for enzyme metabolism. For example, some feel that binge drinking of alcohol may prevent appropriate metabolism of methadone, temporarily increasing concentrations. ${ }^{19}$ One example of preferential metabolism of methadone is its interaction with zidovudine, where increased zidovudine levels have been described. ${ }^{15}$ On the other hand, methadone appears to decrease the concentration of stavudine and didanosine by apparently decreasing their absorption. ${ }^{61}$ Finally, both alcohol and benzodiazepines have been associated with increased risk for respiratory depression in patients using opioids. ${ }^{18}$

\section{CONCLUSION}

In summary, methadone has important therapeutic applications beyond methadone maintenance for opioid dependence. It is a viable choice for patients with neuropathic pain, for pain resistant to treatment with other opioid analgesics, and for situations where dose limiting side effects occur from other opioid agents. Practitioners who prescribe methadone need to be familiar with its unique pharmacokinetic profile, side effects, and potential drug interactions to ensure safe, effective use of this agent.

\section{Authors' affiliations}

R Brown, University of Wisconsin Department of Family Medicine and Department of Population Health Sciences, and Madison Health Services Methadone Treatment Facility, Madison, Wisconsin, USA

C Kraus, University of Wisconsin Department of Pharmacy, Madison, Wisconsin, USA

M Fleming, University of Wisconsin Department of Family Medicine, Madison, Wisconsin, USA

S Reddy, University of Wisconsin Medical School, Madison, Wisconsin, USA

\section{REFERENCES}

1 Morley J, Makin M. The use of methadone in cancer pain poorly responsive to other opiates. Pain Reviews 1998;5:51-8.

2 Bruera E, Pereira J, Watanabe S, et al. Opioid rotation in patients with cancer pain. A retrospective comparison of dose ratios between methadone, hydromorphone, and morphine. Cancer 1996;78:852-7.

3 Ayonrinde OT, Bridge DT. The rediscovery of methadone for cancer pain management [comment]. Med J Aust 2000; 173:536-40.

4 Bruera E, MacMillan K, Hanson J, et al. Palliative care in a cancer center. Results in 1984 versus 1987. J Pain Symptom Manage 1990;5:1-5.

5 Crews J, Sweeney N, Denson D. Clinical efficiency of methadone in patients refractory to other mu-opioid receptor agonist analgesics for management of terminal cancer pain. Cancer 1993;72:2266-72.

6 de Conno F, Groff L, Brunelli C, et al. Clinical experience with oral methadone administration in the treatment of 196 advanced cancer patients. J Clin Oncol $1996 ; 14: 2836-42$.

7 Leng G, Finnegan M. Successful use of methadone in nociceptive cancer pain unresponsive to morphine. Palliat Med 1994;8:153-5.

8 Mercadante S, Casuccio A, Fulfaro $F$, et al. Switching from morphine to methadone to improve analgesia and tolerability in cancer patients: a prospective study. J Clin Oncol 2001;19:2898-904. 
9 Ripamonti C, Bianchi M. The use of methadone for cancer pain. Hematol Oncol Clin North Am 2002; 16:543-55.

10 Daeninck PJ, Bruera E. Reduction in constipation and laxative requirements following opioid rotation to methadone: a report of four cases. J Pain Symptom Manage 1999;18:303-9.

11 Gardner-Nix JS. Oral methadone for managing chronic nonmalignant pain J Pain Symptom Manage 1996;11:321-8.

12 Belluck P. Methadone, once the way out, suddenly grows as a killer drug New York Times 9 February 2003 (section 1).

13 Press A. Methadone overdose deaths on rise in MD. The State 7 January 2004 (section 1).

14 Hammack L. Methadone deaths on rise in Southwest Virginia. The Roanoke Times 20 July 2002.

15 Eap C, Buclin T, Baumann P. Interindividual variability of the clinical pharmacokinetics of methadone. Clin Pharmacokinet 2002;41:1153-93.

16 Inturrisi CE. Clinical pharmacology of opiods for pain. Clin J Pain 2002; 18:S3-13.

17 Lotsch J, Skarke C, Tegeder I, et al. Drug interactions with patient-controlled analgesia. Clin Pharmacokinet 2001;41:31-57.

18 White J, Irvine R. Mechanisms of fatal opioid overdose. Addiction 1999:94:961-72.

19 Moolchan E, Umbricht A, Epstein D. Therapeutic drug monitoring in methadone maintenance: choosing a matrix. J Addict Dis 2001;20:55-73.

20 Ball J, Ross A. The effectiveness of methadone maintenance treatment. New York, NY: Springer-Verlag, 1991

21 National Institute on Drug Abuse. Heroin abuse and addiction. Rockville, MD US Department of Health and Human Services, National Institute on Drug Abuse, 2000 (publication number 00-4165)

22 Gunne L, Gronbladh L. The Swedish methadone maintenance program: a controlled study. Drug Alcohol Depend 1981;7:249-56.

23 Newman R, Whitehill W. Double-blind comparison of methadone and placebo maintenance treatments of narcotic addicts in Hong Kong. Lancet 1979; ii:485-8.

24 Stenbacka M, Leifman A, Romelsjo A. The impact of methadone on consumption of inpatient care and mortality with special reference to HIV status. Subst Use Misuse 1998;33:2819-34.

25 Ward J, Hall W, Mattick R. Role of maintenance treatment in opioid dependence. Lancet 1999;353:221-6.

26 Barnett P. Hui S. The cost-effectiveness of methadone maintenance. Mt Sinai J Med 2000;67:365-74

27 Ling W, Charuvastra C, Kaim SC, et al. Methadyl acetate and methadone as maintenance treatments for heroin addicts. A Veterans' Administration cooperative study. Arch Gen Psychiatry 1976;33:709-20.

28 Strain E, Stitzer M, Liebson I, et al. Dose-response effects of methadone in the treatment of opioid dependence. Ann Intern Med 1993;1 19:23-7.

29 Ripamonti C, Groff L, Brunelli C, et al. Switching from morphine to oral methadone in treating cancer pain: what is the equianalgesic dose ratio? J Clin Oncol 1998;16:3216-21.

30 Nauck F, Ostgathe C, Klaschik E, et al. A German model of methadone conversion [abstract 90]. Abstracts of the 13th MASCC/ISOO International Symposium. Copenhagen, 2001

31 Reilly PM, Sees KL, Shopshire MS, et al. Self-efficacy and illicit opioid use in a 180-day methadone detoxification treatment. J Consult Clin Psychol 1995;63:158-62

32 Dyer KR, White JM. Patterns of symptom complaints in methadone maintenance patients. Addiction 1997;92:1445-55.

33 Specka M, Finkbeiner T, Lodemann E, et al. Cognitive-motor performance of methadone-maintained patients. Eur Addict Res 2000;6:8-19.

34 Hauri-Bionda R, Bar W, Friedrich-Koch A. [Driving fitness/driving capacity of patients treated with methadone]. Schweiz Med Wochenschr 1998; 128:1538-47.

35 Longwell B, Betz T, Horton $\mathrm{H}$, et al. Weight gain and edema on methadone maintenance therapy. Int J Addict 1979;14:329-35.
36 Ragni G, De Lauretis L, Gambaro V, et al. Semen evaluation in heroin and methadone addicts. Acta Eur Fertil 1985; 16:245-9.

37 Cicero TJ, Bell RD, Wiest WG, et al. Function of the male sex organs in heroin and methadone users. N Engl J Med 1975;292:882-7.

38 Mendelson JH, Mello NK. Plasma testosterone levels during chronic heroin use and protracted abstinence: study of Hong Kong addicts. NIDA Res Monogr 1978;19:142-8.

39 Mendelson JH, Mendelson JE, Patch VD. Plasma testosterone levels in heroin addiction and during methadone maintenance. J Pharmacol Exp Ther 1975:192:211-17.

40 Mendelson JH, Meyer RE, Ellingboe J, et al. Effects of heroin and methadone on plasma cortisol and testosterone. J Pharmacol Exp Ther 1975; 195:296-302.

41 Ragni G, De Lauretis L, Bestetti O, et al. Gonadal function in male heroin and methadone addicts. Int J Androl 1988;11:93-100.

42 Spring WD Jr, Willenbring ML, Maddux TL. Sexual dysfunction and psychological distress in methadone maintenance. Int $J$ Addict 1992;27:1325-34.

43 Yuan $\mathrm{C}$, Foss J, $\mathrm{O}^{\prime}$ Connor $\mathrm{M}$, et al. Gut motility and transit changes in patients receiving long-term methadone maintenance. J Clin Pharmacol 1998;38:931-5.

$44 \mathrm{Cobb}$ M, Desai J, Brown L Jr, et al. The effect of fluconazole on the clinical pharmacokinetics of methadone. Clin Pharmacol Ther 1998;63:655-62.

45 Herrlin K, Segerdahl M, Gustafsson LL, et al. Methadone, ciprofloxacin, and adverse drug reactions. Lancet 2000;356:2069-70.

46 Bertschy G, Eap B, Powell K, et al. Fluoxetine addition to methadone addicts: pharmacokinetic aspects. Ther Drug Monit 1996;18:570-2

47 Alderman CP, Frith PA. Fluvoxamine-methadone interaction. Aust N Z J Psychiatry 1999:33:99-101.

48 DeMaria PA Jr, Serota RD. A therapeutic use of the methadone fluvoxamine drug interaction. J Addict Dis 1999;18:5-12

49 Begre S, von Bardeleben U, Ladewig D, et al. Paroxetine increases steady state concentrations of (R)-methadone in CYP2D6 extensive but not poor metabolizers. J Clin Psychopharmacol 2002;22:211-5.

50 Hamilton SP, Nunes EV, Janal M, et al. The effect of sertraline on methadone plasma levels in methadone-maintenance patients. Am J Addict 2000;9:63-9.

51 Ottomanelli G. Methadone patients and alcohol abuse. J Subst Abuse Treat 1999:16:113-21.

52 Reimann G, Barthel B, Rockstroh JK, et al. Effect of fusidic acid on the hepatic cytochrome P450 enzyme system. Int J Clin Pharmacol Ther 1999;37:562-6.

53 Raistrick D, Hay A, Wolff K. Methadone maintenance and tuberculosis treatment. BMJ 1996:313:925-6.

54 Clarke SM, Mulcahy FM, Tija J, et al. The pharmacokinetics of methadone in HIV-positive patients receiving the non-nucleoside reverse transcriptase inhibitor efavirenz. Br J Clin Pharmacol 2001;51:213-7.

55 Altice FL, Friedland GH, Cooney EL. Nevirapine induced opiate withdrawal among injection drug users with HIV infection receiving methadone. AIDS 1999:13:957-62

56 Clarke SM, Mulcahy FM, Tjia J, et al. Pharmacokinetic interactions of nevirapine and methadone and guidelines for use of nevirapine to treat injection drug users. Clin Infect Dis 2001;33:1595-7.

57 Bart PA, Rizzardi PG, Gallant S, et al. Methadone blood concentrations are decreased by the administration of abacavir plus amprenavir. Ther Drug Monit 2001;23:553-5.

58 McCance-Katz EF, Farber S, Selwyn PA, et al. Decrease in methodone levels with nelfinavir mesylate. Am J Psychiatry 2000;157:481.

59 Gerber JG, Rosenkranz S, Segal Y, et al. Effect of ritonavir/saquinavir on stereoselective pharmacokinetics of methadone: results of AIDS Clinical Trials Group (ACTG) 401. J Acquir Immune Defic Syndr 2001;27:153-60.

60 Iribarne C, Berthou F, Carlhant D, et al. Inhibition of methadone and buprenorphine N-dealkylations by three HIV-1 protease inhibitors. Drug Metab Dispos 1998;26:257-60.

61 Rainey PM. HIV drug interactions: the good, the bad, and the other. Ther Drug Monit 2002;24:26-31. 